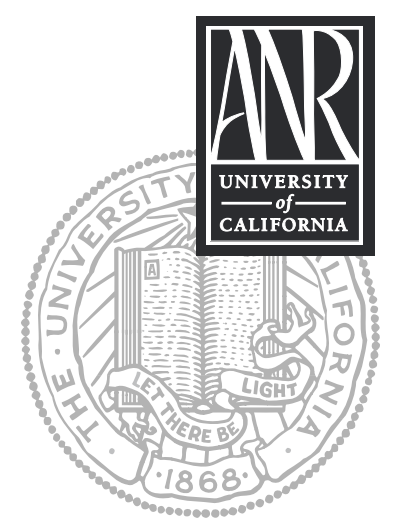

UNIVERSITY OF CALIFORNIA

Division of Agriculture and Natural Resources http://anrcatalog.ucdavis.edu

\title{
FOREST STEWARDSHIP SERIES 16 Forest Pests and Diseases
}

\author{
HEATHER MORRISON, California Registered Professional Forester, Camptonville, CA; \\ CLARALYNN NUNAMAKER, California Registered Professional Forester, Scotland, UK; \\ JOHN LEBLANC, California Registered Professional Forester, Garden Valley, CA; GREGORY \\ GIUSTI, UCCE Forest Wildland Ecology Advisor, Mendocino County; GARY NAKAMURA, \\ UCCE Forestry Specialist, Department of Environmental Science, Policy, and Management, \\ University of California, Berkeley
}

\begin{abstract}
INSECTS
Insects are a natural and necessary part of a healthy forest ecosystem; most insect species are actually beneficial. They speed decay of dead vegetation, releasing nutrients for other plants. Many types of wildlife require insects for food. Bees and other insects pollinate forest plants. Some insects prey on other insects that are harmful to plants, keeping pest outbreaks in check.
\end{abstract}

Many insect populations experience a natural "boom-bust" cycle.

\section{Objective}

Understand that forest insects, animals, and diseases are natural and necessary parts of the forest ecosystem and that they become pests only when they reach excessive levels in a forest.

\section{Competencies}

- Recognize the symptoms of damage to trees due to environmental stress vertebrate and invertebrate animals, and disease.

- Living in the forest: dealing with forest insects and pests

- Become familiar with integrated pest management strategies and practices.

\section{Related Forest Stewardship} Series Publications

- Forest Ecology, ANR Publication 8233

- Forest Vegetation Management, ANR Publication 8236
Every year fertile adults or pupae survive the winter and emerge in the spring. They reproduce and increase in number through the summer and decline again in the winter. Environmental conditions and food availability control their populations. For those that feed on trees (leaves or sugars in the sap), food availability increases when the trees are under stress and are less able to defend against or rebound from insect attack. When susceptible trees are abundant due to prolonged stress, insect populations increase to the extent that food is available. After an initial "boom" period that may last for several generations, the insects reach a level that is no longer sustainable by the available food. The population then "crashes" until the next cycle begins again. The crash may be caused in part by a buildup in the populations of natural enemies of the insects (birds, predatory insects) who themselves are responding to an increased supply of food (insects). When insect outbreaks of this kind are widespread and prolonged, there can be immense amounts of tree mortality. More commonly, tree mortality due to forest insects is localized, limited to a few trees in a small area. In many cases, healthy trees can repel insect attacks or survive them.

Insects kill more trees annually than wildfire. However, they usually take their toll on individual trees or small groups of trees, unlike the spectacular large-scale destruction of forest fires. While insects may be the identifiable cause of tree injury and death, the underlying reason for insect damage is that trees are in poor condition due to stress. Stress is caused by drought, competition for resources among trees, or other environmental conditions. Insects challenge trees constantly, but generally only the stressed or unhealthy trees are successfully attacked and succumb. Maintaining healthy, vigorously growing trees is the best defense against insects.

\section{Bark Beetles and Engraver Beetles}

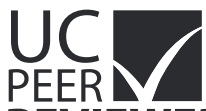

Bark beetles and engraver beetles, though only about the size of a grain of rice, are the most important forest insect pests in California. They enter trees by boring through the bark. Several species attack most of the commercial conifer species in California. 

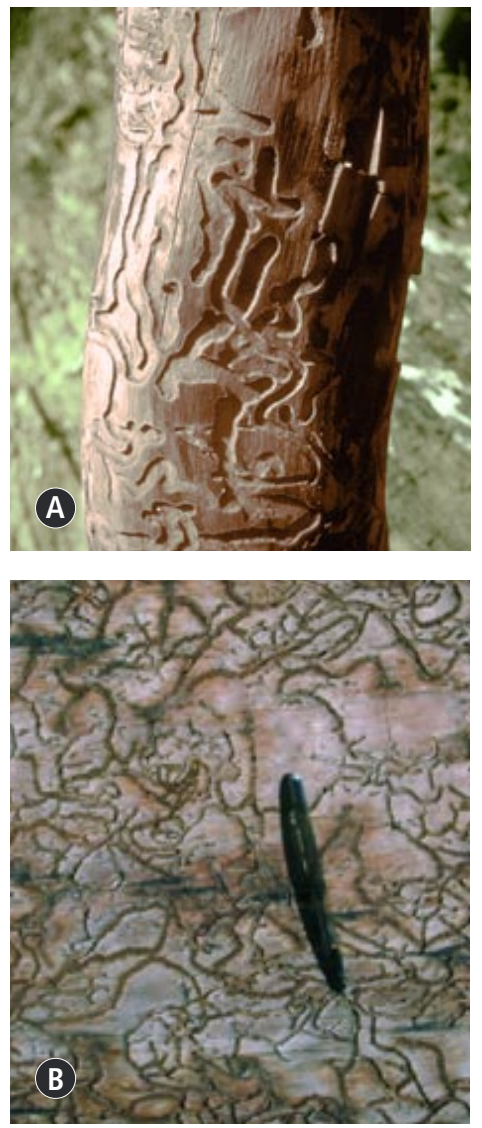

Figure 1. A: Bark beetle damage. Photo: (C) California Academy of Sciences. B: Galleries of the western pine beetle. Larvae feeding on the inner bark (phloem tissue) of ponderosa pine create tunnels that disrupt sap and water flow in the tree. Photo: Gary Nakamura.
These insects generally attack stressed or weakened trees. They often work together: engravers may attack first, weakening a tree, followed by bark beetles, which can kill the tree. General reddening of the foliage in the tops of pine and fir trees is the most noticeable sign of successful bark beetle and engraver attack.

Female beetles lay eggs in tunnels they excavate beneath the bark (fig. 1). The eggs hatch and the larvae feed on the inner bark, disrupting the conductive tissue of the tree (phloem) and eventually girdling the trunk. Bark beetles can also carry a fungus that infects attacked trees, blocking the water-conducting tissues of the tree. Bark beetles attack trees near the base of a tree, while engravers are found near the top. The pattern of the tunnels made by the larvae is characteristic of the species of beetle. Removing a small piece of bark and noting the tunnel pattern can usually yield a positive identification.

Pitch tubes, small bubble-gum-like blobs of sap and sawdust that erupt on the bark of the tree, indicate bark beetle attacks (fig. 2). Pitch tubes are a tree's defense mechanism. If a tree is healthy and has adequate sap, it can often "pitch out" the invading beetle before the beetle can successfully lay eggs. If the tree is under stress or weak, it may not have sufficient sap to pitch the beetle out. In that case the beetle can successfully create an egg gallery and lay eggs. Beetles in successfully attacked trees emit a chemical scent, a pheromone, which attracts other beetles to the weak, susceptible tree, resulting in a mass attack that will kill the tree. Single, isolated beetle attacks are common and not lethal, but under stressful conditions such as a prolonged drought, many stressed trees can produce many beetles that generate mass attacks on trees.

Trees killed by bark beetles should be salvage-harvested quickly to minimize insect spread and to capture the tree's economic value before decay sets in. If the affected logs are not merchantable, remove the bark and cut and split the wood for firewood. This will dry out the inner bark and make the wood less palatable to insects.

\section{Foliage Attackers and Other Insects}

Insects that attack foliage weaken the tree by reducing the amount of food the tree can manufacture. Most trees can tolerate partial defoliation, though this may make them more susceptible to bark beetle attack. Repeated or total defoliation can kill a tree outright (fig. 3).
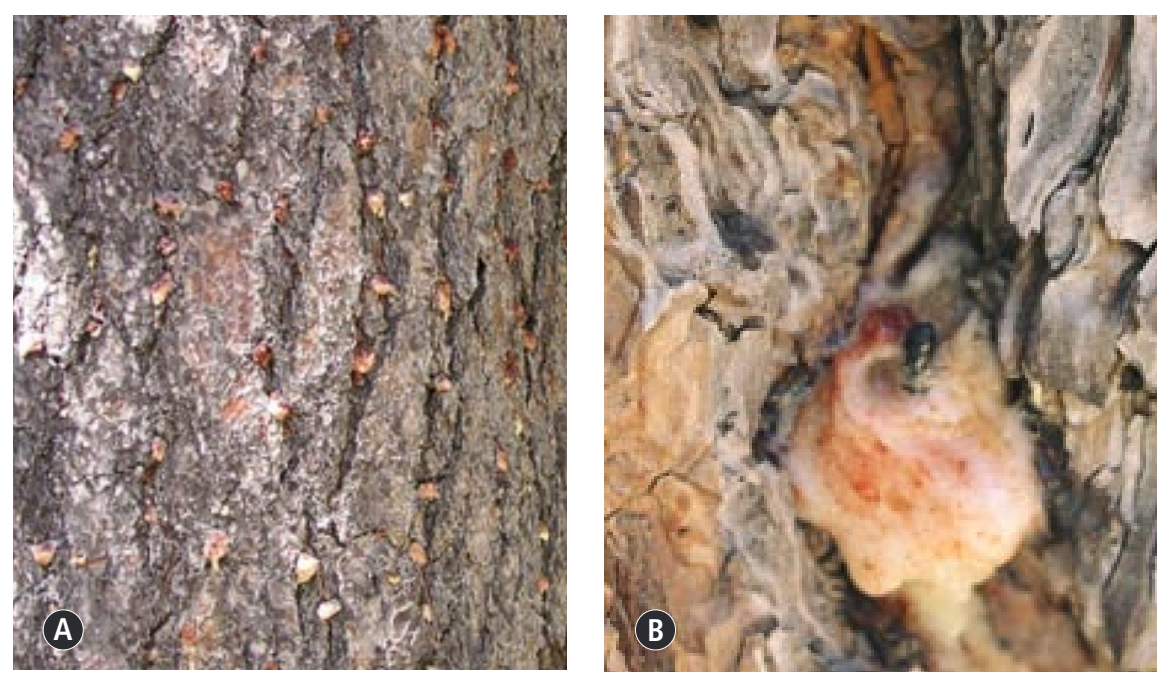

Figure 2. A: Pitch tubes on a pine tree. B: Close-up of pitch tube with bark beetle that was killed and pitched out. Photos: Gary Nakamura. 


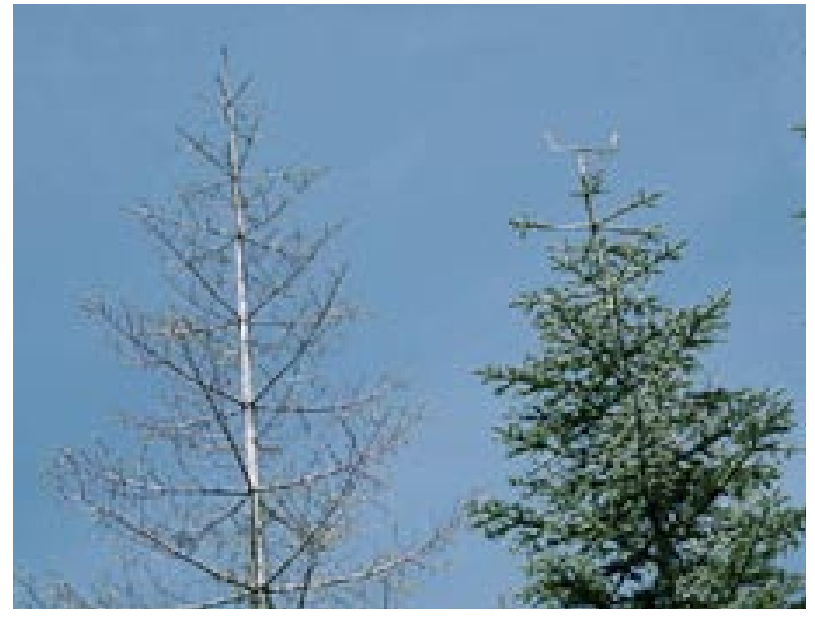

Figure 3. A defoliated white fir, the preferred host for Douglas-fir tussock moth in California, stands next to a red fir, a nonhost tree species. Photo: Courtesy Don Owen, CAL FIRE.
Foliage insects can be found while they are feeding. Look for damaged leaves and needles. Egg masses, usually small pouches or webs attached to protected spots on the bark or under branches and leaves, are easily detected.

Insects also attack twigs, buds, cones, and roots. Look for a decline in tree vigor or damage to the specific part. Be familiar with your forest and notice changes. Respond quickly to insect outbreaks.

\section{Insect Control}

Human attempts at insect control in forests are usually futile and may actually prolong an epidemic. Chemical or other insect control measures are expensive and often ineffective in forests because large areas must be treated and insects do not recognize property boundaries. While individual trees might be protected with insecticide treatments, only landscape trees are probably worth the cost and effort. Also, many insecticides are nonspecific, killing beneficial as well as pest insects.

Learn about insect pests specific to your area. Use strategies to prevent their occurrence or limit their effect. The key to preventing excessive damage to your forest by insects is to minimize stress to trees. This is only partly possible through management. Stresses due to prolonged drought are not preventable. What is possible is to implement silvicultural practices that promote healthy, vigorous trees. Techniques to consider include:

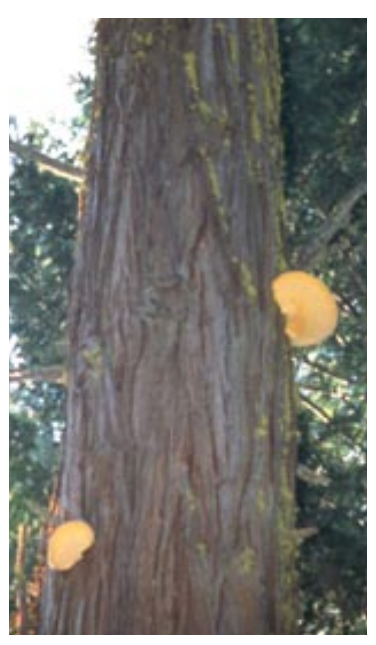

Figure 4 . Oligoporus amarus fruiting bodies on incense cedar, the only known host for this fungus. The fungus attacks the heartwood and causes pocket dry rot. It is usually found in trees older than 150 years old. The fungus enters through fire scars, large open knots, and broken branch stubs. Photo: Gary Nakamura.
- Thin dense stands of trees to maintain good live crowns, improving the vigor of the trees.

- Remove high-risk trees (generally those with poor crowns and vigor) during harvesting operations.

- Plan all management operations to minimize damage to the remaining trees. Insects and diseases can invade trees through logging wounds.

- When available, plant seedlings that are resistant to insects and disease.

- Plant a variety of species where appropriate. Large areas of a single species are more susceptible to attack than stands of mixed species.

\section{DISEASES}

A tree is generally considered to be diseased when it has a symptom such as discolored leaves, dieback in the crown, or fruiting bodies (fungus) on the stem. These symptoms may be caused by fungi, bacteria, parasitic plants and animals (usually insects), or by nonbiological agents such as smog, chemicals, wind, or extreme temperatures (frost, heat). To understand and properly address the problem the specific cause must be determined. This is not always so simple because a combination of factors can often cause the observed symptoms (fig. 4). As with insects, most biologically caused diseases are a natural and necessary part of the forest ecosystem. Fungi, bacteria, and insects break down and decompose organic matter, creating soil humus. They reduce fuels and return nutrients to the soil. These are essential functions of a healthy forest ecosystem.

What we consider a disease is a disturbance of the normal functions of a tree or the deterioration of its parts. When this disturbance occurs sporadically throughout a forest it goes undetected. When it occurs over large, continuous areas, it may be a disease problem that should be addressed. 


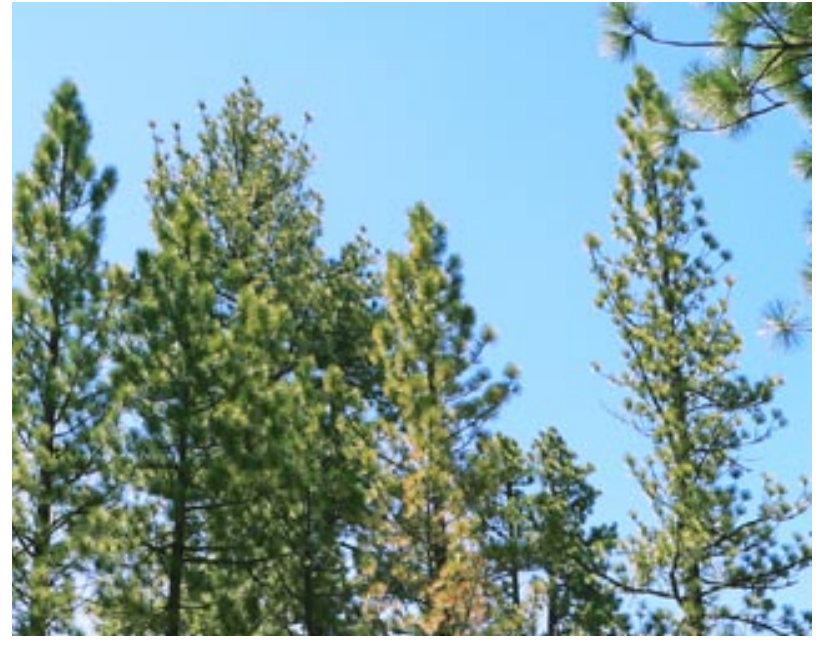

Figure 5. The ponderosa pine on the far right has a thin crown and "poodle tailed" foliage, suggesting a root disease or other systemic problems causing earlier years' needles to drop prematurely. Pine needles are usually retained for 3 to 4 years on a branch before being shed. Photo: Gary Nakamura.
Diseases may be difficult to identify until they have clearly damaged the tree. If symptoms are observed, start with the obvious: Is there some environmental condition that is causing the symptom? For example, has there been recent equipment operation or grading near the tree? If several trees or an area of forest is affected, is there some pattern? For example, if only one species is affected, it might suggest a species-specific organism rather than a nonspecific environmental condition; or if mortality appears in a circular pattern, it might suggest a fungal root disease. Diagnosing the causes of symptoms observed in trees is much like a medical diagnosis. Many different causes may manifest similar symptoms. But, like bark beetles that have characteristic tunnel patterns, some diseases have very specific identifiable symptoms.

\section{Heart Rots}

Heart rots are the leading cause of wood decay. The fungi that cause the rot enter the tree through logging wounds, animal damage, dead branches, or any injury that damages the bark and exposes the inner part of the tree. Look for large, shelflike mushrooms (conks) on tree stems or for mushrooms in the soil around the tree (fig. 4). These are the fruiting bodies of fungi that cause disease and decay. Also, a hollow sound when you tap on the tree indicates heart rot. Preventing injury to trees is the most effective form of control. You may want to salvage-harvest damaged trees. During harvests, "rub" trees are often designated to sustain damage to protect other trees, and these rub trees are removed when the harvest is completed.

The presence of conks indicates significant deterioration inside the tree. The tree may be structurally unsound. If it poses a hazard to people or structures it should be removed. Where possible, trees with heart rot should be left for the wildlife habitat values they provide. They are easily excavated to make cavities for nests and they also make excellent snags.

\section{Root Disease}

Root diseases are fungal diseases whose symptoms show on the whole tree crown uniformly, as compared to insects, foliar diseases, and parasitic plants that tend to affect only certain parts of the tree. If all or most of the tree leaves or needles are yellowing, dying, or shedding for no apparent reason, root problems are usually the cause. Conifers retain their foliage for a number of years; needles on pines are usually retained for 4 or more years. Root problems may reduce needle retention to 1 or 2 years. This will make the crowns more open and thin and give branches a tufted or "poodle tail" appearance (see fig. 5).

Root diseases spread from tree to tree by root contact and fungal growth through the soil and are difficult to detect and even more difficult to control. Look for fruiting bodies (mushrooms) on and around the base of the tree. Bark beetles often successfully attack trees weakened by root disease. Thus beetles may be the immediate cause of death, but root disease is the ultimate cause.

Disease centers, in which a group of trees die, are another good indicator of root disease (fig. 6). Fungi grow in a radial pattern through the soil, creating fairy rings of mushrooms in your lawn and circular disease centers in the forest. Trees adjacent to dead trees are often infected, though they do not show symptoms until the next year when moisture stress finally browns the leaves. Some root diseases become established 


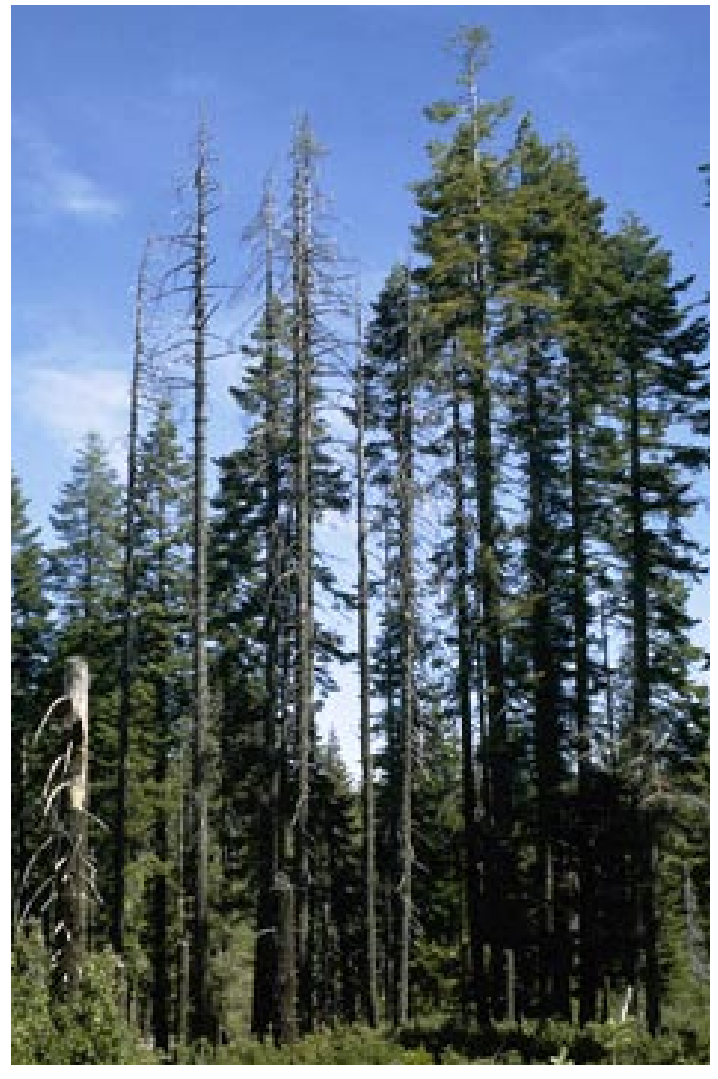

Figure 6. The center of annosum root disease in a stand of white fir, eastern Shasta County. Photo: Courtesy Don Owen, CAL FIRE. when fungus spores land on and colonize a freshly cut stump. One particularly serious root disease, caused by the fungus Heterobasidion annosum, can be prevented by powdering freshly cut stumps with borax (sodium borate).

Root disease can be managed in part by managing the species composition of the forest. Root diseases are typically host speciesspecific, affecting only one tree species. Increasing species diversity or reducing the relative proportions of susceptible species can reduce the incidence or extent of disease. Affected trees and sometimes trees around them of the same species that may have been infected should be removed to prevent further spread.

\section{Rusts}

Rusts are fungi that enter the tree through the needles. Rusts require an alternate host plant for the disease to complete its life cycle. Spores can travel hundreds of miles on the wind, so the alternate host could be far away.

The most destructive rust in California is the white pine blister rust that infects sugar pine and other pines in the fiveneedle white pine group. It is an exotic disease that was introduced to North America in the early 1900s on seedlings of eastern white pine from Europe. Symptoms are random flagging (dead, brown-needled branches) in tree crowns. Close examination of these branches reveals a spindlelike swelling of the branch filled with orange spores. Eventually, the rust will grow into the main stem and kill the tree or make the tree more susceptible to successful beetle attack.

The alternate hosts for white pine blister rust are currant and gooseberry. In the 1940s, control was attempted by eradicating the alternate host, but this proved ineffective because the eradication was incomplete and the gooseberry regenerated. Research is underway to find and produce sugar pine that is resistant to blister rust and would be safe to use in reforestation projects.

\section{Sudden Oak Death}

Sudden oak death (SOD) is caused by the fungus Phytophthora ramorum (fig. 7). Since its appearance in 1995, sudden oak death has killed tens of thousands of coast live oak, black oak, and tanoak trees in northern California. It can also infect leaves and branches of other plants that are carriers of the disease, including rhododendron, buckeye, madrone, manzanita, bigleaf maple, bay laurel, evergreen huckleberry, and redwood. Carrier species are not killed, nor do they display significant damage, making it difficult to detect infection and control disease transmission.

Sudden oak death has been found as far north in the state as Humboldt County and as far south as Big Sur in Monterey County. As of 2006, it had been identified in 12 California counties: Alameda, Contra Costa, Humboldt, Marin, Mendocino, Monterey, Napa, San Mateo, Santa Clara, Santa Cruz, Solano, and Sonoma. 

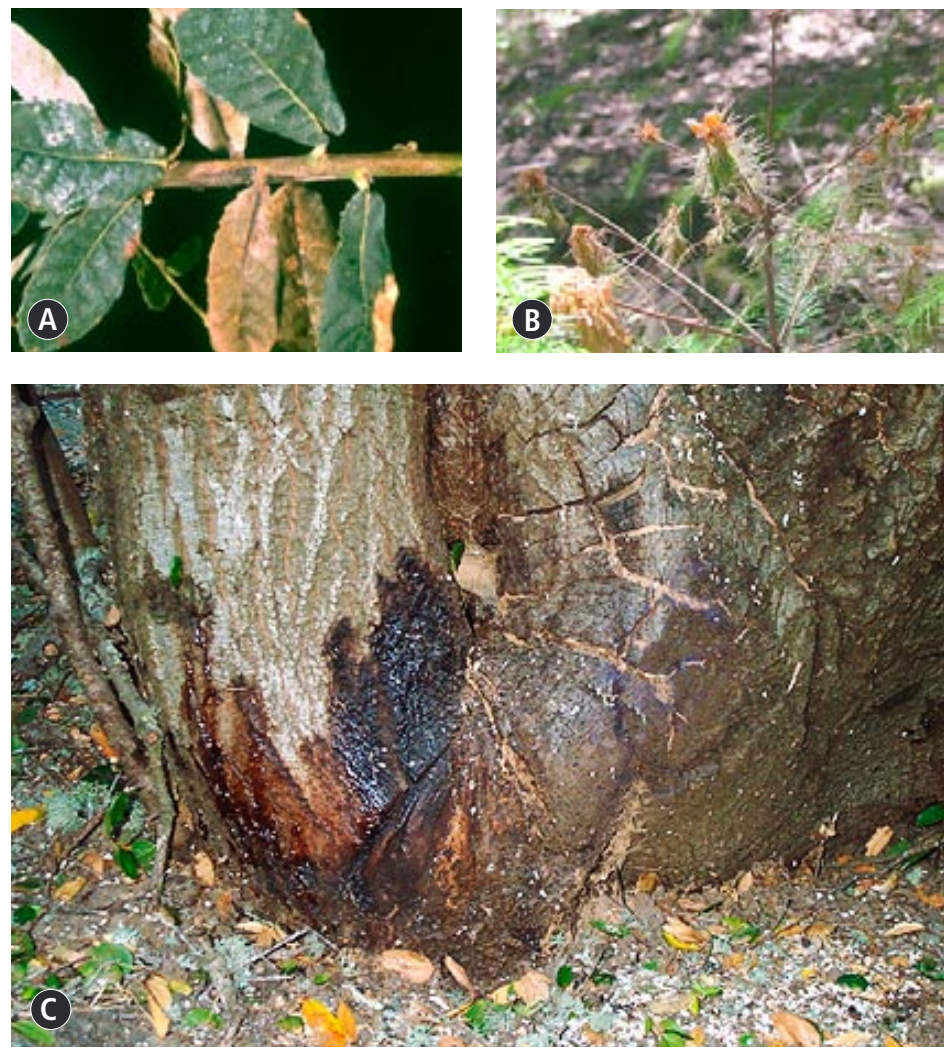

Figure 7. Sudden oak death (SOD) has symptoms very much like other diseases: yellowing and browning of leaves. A: necrotic leaf spots; B: "burned" tips of conifers that are carriers of the disease; $C$ : perhaps most distinguishing is an oozing of reddish-brown sap from oak tree trunks. Photos: Courtesy J. M. Davidson, S. Werres, M. Garbelotto, E. M. Hansen, and D. M. Rizzo, "Sudden Oak Death and Associated Diseases Caused by Phytophthora ramorum," Plant Management Network, July 7, 2003.
Bleeding or oozing of a thick, dark reddishbrown sap is the first symptom to appear on true oaks and tanoak. It typically occurs on the lower portion of tree trunks (below 10 feet) but has been found as high as 60 feet. On tanoak, the first symptom is the drooping and wilting of new growth. Beetles attack weakened trees. Wooddecaying fungi can be seen in the later stages of decline on the trunks of oaks and tanoaks.

Preventing the movement of infected leaves, wood, water, and soil are critical to slowing the spread of this fungus to other oak woodlands, such as in the Sierra Nevada foothills. Plant material and soil should not be moved from coastal areas. Any wood already moved outside the infested area should be burned. Visitors to coastal forests should clean their tires, shoes, and animals' feet thoroughly before leaving the area. Washing with soap and water, Lysol, or 10 percent bleach solution would be better, but any cleaning of mud, leaves, and organic material is helpful. Construction workers should wash equipment well and should not move dirt from one place to another. Ornamental plants that may be hosts, such as rhododendrons, should not be moved from infected counties unless certified to be free of the pathogen.

\section{Dwarf Mistletoe}

Dwarf mistletoe is a serious disease of western conifers. The infection can be identified by an erratic and profuse growth of branches in the crown known as "witches broom." Stem infections show swelling at the infection site. The plant itself is a cluster of yellowgreen stems with a scalelike appearance similar to juniper, but with no leaves (fig. 8). Cut and remove affected trees that have evidence of dwarf mistletoe in the stem of the tree, as the stem will be weakened and subject to breakage above the point of infection. Pruning affected limbs may be sufficient in trees with dwarf mistletoe only in the branches.

Dwarf mistletoe is host species-specific. That is, ponderosa pine dwarf mistletoe infects only ponderosa pine, and white fir dwarf mistletoe infects only white fir. Dwarf mistletoe in tall trees cast their seeds down on understory trees, infecting those of the same species. Infected large trees are usually removed to prevent the infection of smaller trees. In an understory with mixed tree species, the nonhost species will not be infected.

\section{Controlling Forest Diseases}

Most of the general concepts used to control insects also apply to diseases. In fact, many diseases are transmitted by insects and are usually managed by controlling the insect carrier.

As with insect control, prevention through good forest management is the best method of disease control. Chemical control (except in limited areas, high-value nurseries, Christmas tree plantations, or ornamental plantings) is rarely cost effective. Consult with your forester, UCCE forestry or farm advisor, or California Department 

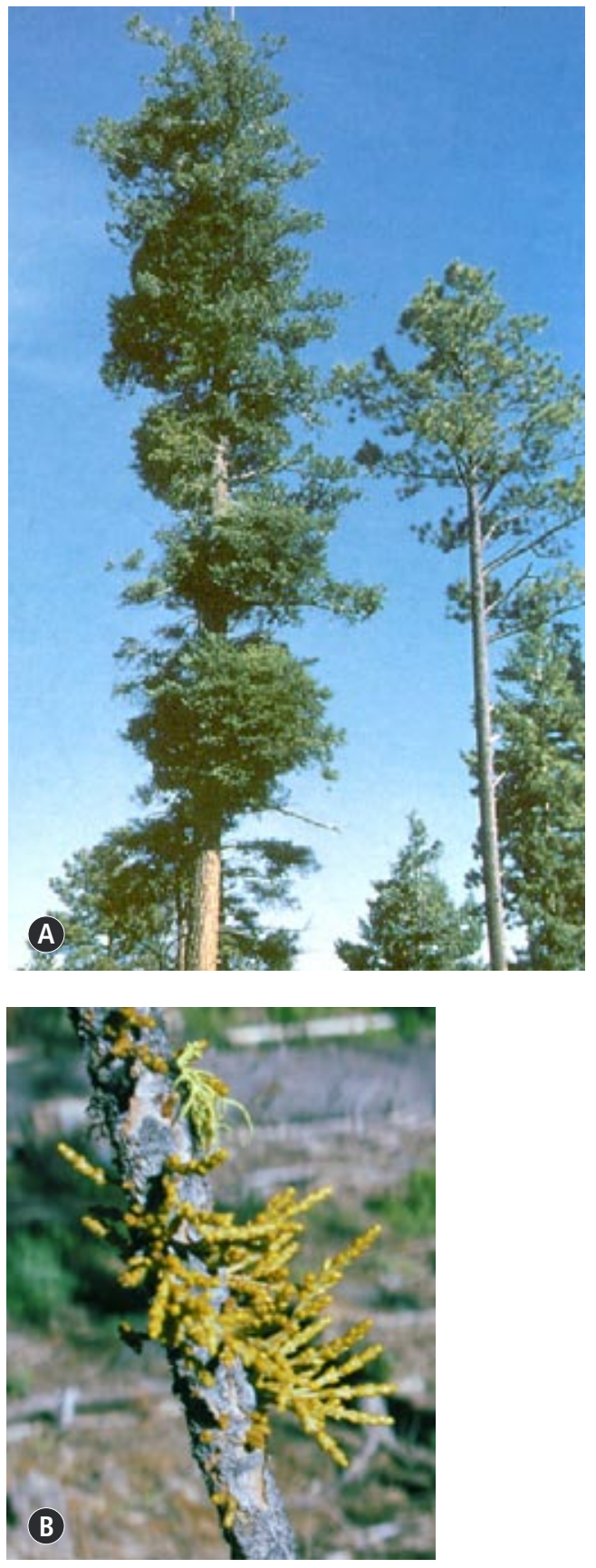

Figure 8. Dwarf mistletoe in ponderosa pine. A: "Witches brooms" or "brooms" of wild branch and foliage growth caused by the dwarf mistletoe. Dwarf mistletow is a parasitic plant that lives on the photosynthate of the host pine tree, but it is not acutely lethal to the tree. Over time the tree will be weakened; broom-laden treetops and branches break off and create openings for fungal diseases and heart rots. $B$ : Close-up of the dwarf mistletoe plant on a ponderosa pine branch. Photos: Gary Nakamura. of Forestry and Fire Protection (CAL FIRE) service forester to learn about diseases you should be concerned about and strategies to prevent them. Christmas tree plantations, given their high value and limited area, may warrant more extensive control methods such as spraying fungicides or insecticides.

\section{WILDLIFE PESTS}

Most people live in or visit a forest for the aesthetic values found there. Seeing and hearing wildlife helps us to feel that the forest is "alive." However, forest wildlife can create conflicts with forest management goals.

In most cases, significant animal damage occurs in young plantations or affects young trees. Simply put, the smaller the tree, the greater the risk of damage from chewing, browsing, rubbing, or climbing. As a tree or plantation ages it can sustain higher levels of animal impacts and continue to survive.

\section{Seedlings}

Seedlings are at the highest risk of animal damage. Seedlings have little protection against or resistance to the damage that can occur from feeding by pocket gophers, voles, rabbits, and deer. Generally, the tree species most severely impacted by these wildlife species are the "whitewood" conifers (pines, firs, and Douglas-fir). Techniques that can inhibit feeding damage include TreeShelters, Vexar tubing, and chemical repellants. The tube-style products can generally protect small seedlings for several years until they outgrow the tube. The repellants, though effective, must be applied frequently (particularly during the rainy season) if they are to be effective. Mowing and tilling can also minimize damage from rodents by making the site less attractive to these animals. Care must be taken not to damage the seedlings with the machinery.

\section{Saplings and Pole Trees}

As a tree matures, it becomes less susceptible to damage from browsing and girdling as it grows beyond the reach of deer (about 5 feet high). Pocket gophers can still pose a threat to the root system, particularly of pine and fir trees. Regular monitoring should be conducted in plantations of these species to ensure that pocket gopher populations are not increasing and damaging the trees. Effective pocket gopher controls include trapping and toxic baits.

In forests dominated by ponderosa pine, porcupines can be a serious threat to intermediate-sized trees. These rodents can severely impact trees by feeding and gnawing on the bark, severing conductive tissue. Contact your local county agricultural commissioner's office to enlist their assistance in designing a management program to limit the damage from porcupines.

\section{Saw Timber and Mature Trees}

Once a tree has matured, most are not susceptible to serious animal damage, but there are exceptions to the rule. Mature Douglas-fir trees have been killed by pocket gophers feeding on their root systems. Mature pine trees can be seriously damaged by tree squirrels. 


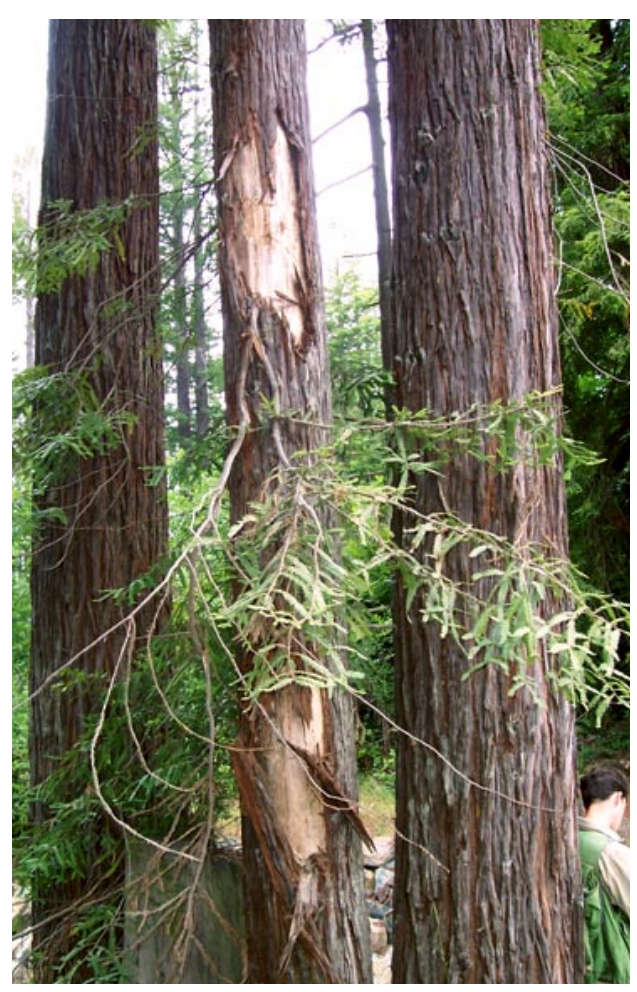

Figure 9. Bark stripping by black bear on sawtimber-sized redwood trees, Humboldt County. Bears strip the bark to access the sugars in the phloem and possibly to mark their territories. Photo: Greg Giusti.
Coast redwood trees are susceptible to damage from wood rats, tree squirrels, and black bear (fig. 9). Tree squirrels and wood rats can feed on the terminal leaders of mature pines and redwoods, creating unsightly, malformed trees. Black bear feeding damage to the bark of coast redwood trees from 11 to 20 inches in diameter at breast height often results in the death of the tree. In most cases, the damage is limited in its extent, and the trees usually survive. If a mature stand of trees is being impacted by these species, seek advice from local California Department of Fish and Game (DFG).

\section{FOREST PESTS AND PEOPLE}

\section{Ticks and Lyme Disease}

Lyme disease is a potentially debilitating and sometimes chronic infection transmitted to humans and other animals by certain ticks. Lyme disease is caused by the bacterium Borrelia burgdorferi. Within 1 to 2 weeks of being infected a "bull's-eye" rash may develop, with fever, headache, and muscle or joint pain (fig. 10). Some people have Lyme disease and do not have any early symptoms. Other people have a fever and other flulike symptoms without a rash.

Avoid being bitten by infected ticks (fig. 10). Whenever possible, avoid entering areas that are likely to be infested with ticks, particularly in spring and summer when nymphal ticks feed.

If you are in an area with ticks, wear light-colored clothing so that you can spot ticks more easily and remove them before they become attached. Wear a long-sleeved shirt and tuck your pants cuffs into your socks. You may also want to wear high-top rubber boots, since ticks are usually located close to the ground.

Applying insect repellents containing DEET (n,n-diethyl-m-toluamide) to clothes and exposed skin and permethrin (which kills ticks on contact) to clothes should also help reduce the risk of tick attachment. DEET can be used safely on children and adults but should be applied according to U.S. Environmental Protection Agency (EPA) guidelines to reduce the possibility of poisoning .

Since transmission of $B$. burgdorferi from an infected tick is unlikely to occur before 24 hours of tick attachment, check for ticks daily and remove them promptly. Embedded ticks should be removed by using fine-tipped tweezers. Cleanse the area with an antiseptic.

You can reduce the number of ticks around your home by removing leaf litter and piles of brush and wood around your house and at the edge of your yard. By clearing trees and brush in your yard, you reduce the likelihood that deer, rodents, and ticks will live there. Cleaning up the area around the house also reduces the fire hazard.

Figure 10. A: Left to right: Western black-legged tick larva, nymph, male, and female. Photo: R.S. Lane, Insect Biology, UC Berkeley. B: Erythema migrans, the skin rash common in the early stage of Lyme disease. Photo: (C) Ross Ritter, Potter Valley, CA.
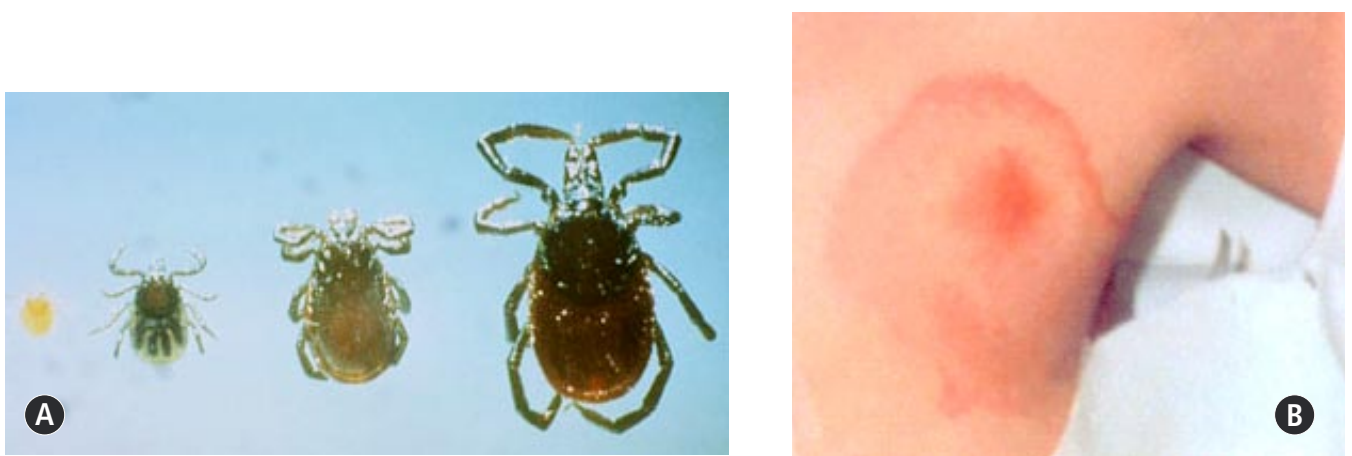


\section{Wasps, Hornets, Yellow Jackets, and Bees}

Wasps, hornets, yellow jackets, and particularly bees are important and necessary parts of a healthy forest ecosystem. Although they become pests when they sting or bite us, our approach should be to avoid them rather than try to eradicate them. When you are in the forest, watch where you step, be aware of your surroundings, and listen for buzzing sounds.

Bald-faced hornets are black and white, build egg-carton gray paper nests in trees the size of footballs, and can be aggressive. If you do disturb hornets, you may be able to evade them by running a short distance, stopping, and slowly stepping to the side without creating an air disturbance, since hornets may continue following the air disturbance. However, it is best not to disturb hornets in the first place.

Yellow jackets, sometimes called meat bees, build paper nests underground and, when disturbed, come boiling up from the ground. The conventional wisdom is that the first hiker in a line arouses a yellow jacket nest, the second gets them angry, and the third one gets stung.

Honey bees are often seen in the forest when hives of bees that were used to pollinate orchards in the spring are brought into forests in the summer to feed on wildflowers.

A variety of wasp species live in the forest. Some, usually very small and unnoticed, lay their eggs in tree leaves and branches (usually oaks), creating galls of plant tissue. These galls can look like golf balls, small cones, or spiked balls in various colors. Galls are not lethal to trees.

\section{INTEGRATED PEST MANAGEMENT (IPM)}

One approach to controlling pests is known as integrated pest management (IPM). IPM is a strategy that takes the entire ecosystem into consideration and recognizes the valuable role that insects and disease play in a healthy forest. It focuses on long-term, systemic control of insects and diseases to prevent them from becoming pests that cause widespread and serious damage, through a combination of techniques including biological control, habitat manipulation, modification of cultural practices, and use of disease resistant varieties.

With IPM, pesticides are not applied routinely; rather, they are used only after monitoring indicates they are needed according to established guidelines. Treatments are made with the goal of affecting only the target organism. Pest control materials are selected and applied in a manner that minimizes risks to human health, beneficial and nontarget organisms, and the environment. IPM requires careful monitoring of the forest to determine whether a pest problem exists and whether the problem is intolerable and requires treatment. In many cases the "no treatment" option is found to be the preferred, most cost-effective approach.

\section{RESOURCES}

Several good sources of information are available on forest pests and diseases. The University of California Division of Agriculture and Natural Resources has online and printed publications on pests, disease, and integrated pest management that may be accessed through the ANR CS Web site, http://anrcatalog.ucdavis.edu/InOrder/Shop/ Shop.asp. The California Forest Pest Council holds conferences and workshops on forest pests and prepares an annual forest pest report; see their Web site at http://www .caforestpestcouncil.org/. The UC Integrated Pest Management Program's has a Web site (http://www.ipm.ucdavis.edu/PMG/PESTNOTES) that provides free information on controlling ticks, Lyme disease and many other pests. The IPM publication on pest control in forests and rights-of-way, which would be of general interest to forest landowners, can be ordered at the ANR CS Web site given above. 
An excellent reference on forest insects, diseases, and animal damage is Pests of the Native California Conifers, by David Wood, Thomas Koerber, Robert Scharpf, and Andrew Storer (University of California Press Natural History Guide Series No. 70, 2003). It can be found in many bookstores or ordered from the UC Press Web site, http://www.ucpress.edu/books/pages/9670.html.

The status and spread of sudden oak death is monitored by the interagency California Oak Mortality Task Force, http://www.suddenoakdeath.org/.

The California Department of Forestry and Fire Protection (CAL FIRE) produces a series of "Tree Notes" leaflets, many of which pertain to management of forest pests; see their Web site, http://ceres.ca.gov/foreststeward/html/treenotes.html.

\section{ENGLISH-METRIC CONVERSIONS}

\begin{tabular}{|l|l|l|l|}
\hline English & $\begin{array}{l}\text { Conversion factor for } \\
\text { English to Metric }\end{array}$ & $\begin{array}{l}\text { Conversion factor for } \\
\text { Metric to English }\end{array}$ & Metric \\
\hline Length & & & \\
\hline inch (in) & 2.54 & 0.394 & centimeter (cm) \\
\hline foot (ft) & 0.3048 & 3.28 & meter (m) \\
\hline yard (yd) & 0.914 & 1.09 & meter (m) \\
\hline mile (mi) & 1.61 & 0.62 & kilometer (km) \\
\hline
\end{tabular}

\section{FOR FURTHER INFORMATION}

To order or obtain printed ANR publications and other products, visit the ANR Communication Services online catalog at http://anrcatalog.ucdavis.edu. You can also place orders by mail, phone, or FAX, or request a printed catalog of our products from:

University of California

Agriculture and Natural Resources

Communication Services

6701 San Pablo Avenue, 2nd Floor

Oakland, California 94608-1239

Telephone: (800) 994-8849 or (510) 642-2431

FAX: (510) 643-5470

E-mail inquiries: danrcs@ucdavis.edu

An electronic version of this publication is available on the ANR Communication Services Web site at http://anrcatalog.ucdavis.edu.

Publication 8246

ISBN-13: 978-1-60107-466-9

(c) 2007 by the Regents of the University of California, Division of Agriculture and Natural Resources. All rights reserved.

The University of California prohibits discrimination or harassment of any person on the basis of race, color, national origin, religion, sex, gender identity, pregnancy (including childbirth, and medical conditions related to pregnancy or childbirth), physical or mental disability, medical condition (cancer-related or genetic characteristics), ancestry, marital status, age, sexual orientation, citizenship, or status as a covered veteran (covered veterans are special disabled veterans, recently separated veterans, Vietnam era veterans, or any other veterans who served on active duty during a war or in a campaign or expedition for which a campaign badge has been authorized) in any of its programs or activities. University policy is intended to be consistent with the provisions of applicable State and Federal laws. 
Inquiries regarding the University's nondiscrimination policies may be directed to the Affirmative Action/Staff Personnel Services Director, University of California, Agriculture and Natural Resources, 300 Lakeside Drive, 6th Floor, Oakland, CA 94612-3550 (510) 987-0096. For a free catalog of other publications, call (800) 994-8849. For help downloading this publication, call (530) 297-4445.

To simplify information, trade names have been used. No endorsement of named or illustrated products is intended, nor is criticism implied of similar products that are not mentioned or illustrated.

This publication has been anonymously peer reviewed for technical accuracy by University of California scientists and other qualified professionals. This review process was managed by the ANR Associate Editor for Natural Resources. 